\title{
THE REAWAKENING OF TEACHING THROUGH AESTHETICS IN EDUCATION: STUDENTS' PERSPECTIVES
}

\section{Author:}

Ramdhani, J1

Ramsaroop, $\mathrm{S}^{1}$

\section{Affiliation:}

'University of KwaZulu-Natal, College of Humanities, School of Social Science Education, South Africa

${ }^{2}$ University of Johannesburg, Faculty of Education, Department of Childhood Education, South Africa

\section{Correspondence to:}

Ramdhani, J

Email:

ramdhanij@ukzn.ac.za

\section{Correspondence to:}

Ramsaroop, S

Email:

saritaram@uj.ac.za

\section{Postal address:}

21 Eastwood Lodge, Phillips Road,

Boksburg,

1459

\section{Dates:}

Published: 01 Des. 2015

How to cite this article: Ramdhani, J. \& Ramsaroop, S., 2015, 'The reawakening of teaching through aesthetics in education: Students' perspectives'. KOERS - Bulletin for Christian Scholarship, 80(2). Available at: http:// dx.doi.org/10.19108/ koers.80.2.2227

\section{Copyright:}

(c) 2015. The Author(s)

Published under the Creative Commons Atribution License.
A multidisciplinary approach to teacher education involves drawing from multiple pedagogies within disciplines, in particular the use of aesthetic methods of teaching, to redefine teaching through continuous reflection. This article reports on the process of pre-service students' interpretation of the sensory contemplation of aesthetic perceptiveness within their academic programmes at a higher education institution and explores how students internalised and applied these aesthetic qualities in their practice. Using a qualitative approach, the findings indicate the positive influence of aesthetically enjoyable and engaging teaching strategies, such as group or whole class discussions that infused technology, on pre-service students' understanding of content knowledge taught in lectures. Reports regarding pre-service students' application of these very strategies at schools during their school experience were positive in terms of their ability to reflect critically before, during and after the lesson, made possible by personal first-hand experiences with the selected strategy. It was found that pre-service teachers believe that for effective teaching to take place, as practitioners, they need to take 'full account of the multi-dimensional cultural world of the learner' and therefore it is recommended that they adopt a multi-dimensional approach that is inclusive of aesthetics in their practice.

KEY WORDS: Aesthetics; teacher education; prior learning; constructivism, pedagogy, higher education; student teacher learning 


\section{INTRODUCTION}

The teaching profession has been plagued by various criticisms ranging from a weak pedagogic knowledge base of teachers to poor learner performance (Rhodes and Bellamy 1999; Pretorius, 2004). More recent criticisms include teachers' poor epistemological and pedagogical knowledge which has contributed to poor teaching of the specialised content (Department of Education, 2007; Department of Basic Education and Higher Education and Training 2011, 4). As such, there are intense debates in the teacher education literature on strategies to improve the quality of teaching and learning both locally and internationally. For example, aspects that have been identified that should be taken into consideration in developing a good teacher include strong content knowledge, a good understanding of how to teach that content (Shulman, 1998), combined with pedagogical learner knowledge (Grimmett and Mackinnon, 1992, cited by Darling-Hammond, 2008:92). Frederick, Cave, and Perencevich (2010, 317) contend that 'culturally responsive practice' causes pre-service teachers to focus not only on the discipline knowledge, pedagogical methods but to also be mindful of 'the assumptions and stereotypes that they bring into the classroom'. We would further add that teaching using these principles can bring about aesthetic experiences for learners in the classroom if the teacher infuses passion and imagination into his/her planning and implementation. Teacher training will therefore need to provide learning opportunities for student teachers that combine theoretical knowledge with classroom practice in ways that can inject new energy, excitement and enjoyment in the teaching and learning experience.

The Bachelor of Education degree at the University of Johannesburg consists of a module that allows students to implement pedagogies, which includes applying an aesthetic learning experience emanating from a teaching strategy used in their coursework to a practice situation at schools. Here the students are given the opportunity to explore how these multiple pedagogies, including aspects of aesthetics, play out in the lesson that they deliver during their teaching practice. Promoting a constructivist learning environment is encouraged as it provides a rich environment for learners to express themselves. However, Heron and Reason (1997:277) argue that "constructivist views tend to be deficient in any acknowledgement of experiential knowing, that is, knowing by acquaintance, by meeting, by felt participation in the presence of what is there." These scholars base this argument on the silence from constructivist views on the exact nature of experiential knowing (Heron \& Reason, 1997). In addressing these concerns, we contend that the concept of experience in learning is recognised by drawing on Watts (1998:174) who make the claim that the constructivist view of learning proposes that the knowledge be cultivated in such a way that the students shape and manage their experiences to achieve the best results and to negate undesirable results. This was achieved through the use of dialogic instructional teaching strategies such as discussions, debate and question and answer that stimulates thinking, challenges attitudes and beliefs, and develops interpersonal skills (Burbules \& Bruce, 2001).
This article focuses on pre-service student perceptions of the incorporation of aesthetics in teaching. Stimulating creativity, passion and imagination is just one of an array of strategies that prospective educators will need to develop in their teaching. Research has indicated that to become a reflective practitioner, pre-service teachers should be able to assess and explore the success of their practices continuously. Schön's (1983) conceptualization of the reflective practitioner relies on the notion of tacit knowledge in that it foregrounds reflective practice as a knowledge generating activity and advocates an epistemology of practice. As suggested by Macann $(2010,1)$, it is important for people, in this case student teachers, to be given the 'architectural landscape', the time within the lecture to retreat through silence to reflect and then to share their reflection. It is this freedom to continuously imagine, assess, explore and reflect on new ways of doing things that ultimately leads to practical application.

The ability to stimulate passion and creativity in pre-service teachers may, however, not be an easy task. Student teachers have already internalised a range of teaching and learning experiences acquired from the number of years spent at schools as learners and it is these forms of prior knowledge and preconceptions that influence the way that student teachers learn about teaching (Stofflett and Stoddart, 1994; Wubbels, 1992). Adding support to this debate, Muis (2004) provides evidence on the influence of pre-service teachers' personal epistemologies, which reflects how an individual thinks about knowledge (Hofer, 2010), in influencing how they learn in teacher education courses and the extent to which they engage in complex problem-solving. Our use of the term knowledge in this context incorporates both explicit and tacit knowledge as we argue that coursework, which is generally abstract and conveys knowledge that is explicit and tacit knowledge which is acquired through relevant experience or "learning by doing" (Lam, 2000:490) are equally important for student teachers' learning to teach. They are not separate but interact dynamically to form new knowledge (Nonaka \& Takeuchi 1995 cited by Lam, 2000). With many of South African teachers found lacking in epistemological and pedagogical knowledge resulting in poor teaching (Department of Education, 2007; and Department of Basic Education and Higher Education and Training, 2011:4), we can conclude that many pre-service students may not have internalised positive teaching experiences which they can model. We therefore need a different approach whereby students can experience good teaching in an attempt to alter any negative preconceptions of teaching or to strengthen those that are positive.

Students were asked to reflect on a specific teaching strategy that was used in their lectures that they found aesthetically enjoyable and captivating as a learning experience and which added value to their understanding of their coursework. Students were requested to reflect in the following ways: the first was on how the selected strategy influenced them as students; the second was on what they thought the lecturer had to do before and during the lecture to ensure that this strategy was successful. Students were then asked to use this teaching strategy in a lesson that they would teach during their school experience, again followed by a reflection thereof. 
In so doing, it was hoped that students, by drawing on their learning experiences from coursework, would be able to link aesthetics with pedagogic content knowledge, thereby allowing them to become critical thinkers. A view that is supported by scholars such as Gaudelli and Hewitt $(2010,88)$ is that drawing on experience and focused thinking allows one to become a more critical thinker, especially with regard to societal issues. Using a qualitative approach that drew on document analysis, the exploration undertook to look at how students internalised and applied these aesthetic experiences in their practice. The aesthetic experience that we refer to includes student teachers' experiencing a teaching strategy as not just enjoyable and captivating, but in its contribution towards enhancing their understanding of coursework.

In order to understand how aesthetics can be used as a tool for critical thinking to allow for the possibility for change in order to transform student teachers' initial conceptions of teaching, a conceptual analysis of aesthetics and the possibilities it may hold for teaching and learning needed to be interrogated.

\section{A CONCEPTUAL ANALYSIS OF THE TERM AESTHETICS}

When one speaks of aesthetics, immediately the discipline of fine arts and Baumgarten (1744), who coined the term the science of the beautiful, come to mind. However, the concept of aesthetics has since widened to encompass the changes in society and how the concept of art and culture is being defined (Sundin 2000). It is no longer confined to philosophers and art scholars but is now embraced by a wide range of disciplines. Crawford (1987) succinctly draws our attention to the broadness of the word aesthetics and the need to move away from only thinking of aesthetics in relation to beauty. According to a government gazette released by the Ministry of Education in New Zealand (2009), aesthetics is the 'critical evaluation of a piece of art' and 'an appreciation of pleasant and special sensory experiences (usually, visual, aural or tactile' implying that to critically evaluate an experience as pleasant or unpleasant, judgement is necessary. Zangwill (2014) also brings in the notion of aesthetic judgement that uses the term aesthetics not only in relation to beauty but to that which also lacks beauty. Thus, the word aesthetics has the ability to recapture its foundation 'pertaining to sensory contemplation and its objects' (Sparshott, 1982). The infusion of aesthetics as sensory contemplation opens up a range of opportunities for teacher training.

Aligning teaching with the constructivist perspective continues to dominate current theories of learning and teaching (Drake, 1998:153) and can lead to aesthetic experiences when the experience of wonder and excitement in learning is realised (Hansen, 2005) or to use aesthetics to judge an experience as captivating or unexciting (Zangwill, 2014). Gordon (2007) challenges the approach of learning in public schools taking place in an atmosphere of seriousness, strong adherence to rules and standardisation, with very little significant learning being achieved. Gordon (2007) promotes the creation of exciting classroom atmospheres that would have greater success in motivating learners. This is also related to Hook's
(1994) notion of learning linked to excitement and fun in the classroom, with excitement used as a standard by which the lesson can be evaluated.

Promoting pupil-centred and activity-based learning by incorporating learning through visual, auditory, kinaesthetic and tactile means would result in activities become more issue-focused, relevant, practical and skills-based, providing opportunities for learners' investigation and communication (Palmer and Neal, 1994:29). Such learner-centred lessons allow for teaching to have the following two experiences: the incorporation of activities that have a problem-solving dimension and the integration of contemporary issues for students to put under the microscope and discuss. It is therefore important for teachers to explore different teaching techniques so as to ensure that this thread of learning is optimally captured. Such assertions are supported by Dewey (1904) who maintains that through experimentation with various teaching techniques, pre-service teachers are able to gain knowledge about teaching and learning that is tangible and comprehensible. This would entail that teachers continuously question the success of the strategies employed in the lesson and make the necessary revisions and improvements. By continuously reflecting and theorising on the success of the lesson through the lens of aesthetic understanding, pre-service teachers would allow learners in the classroom to link learning with real life experiences.

Ganger (2006: 46) draws our attention to Dewey's assertion that aesthetics can be achieved not only through art, but by including the system of dialogue or discourse in society. Goldman (2010: 5) echoes this view by stating that meaning is created by one's engagement with society, with the thinking being directly related to the construction that emerges from this engagement in society

This leads us to the question of reflection. Reflection means that teachers constantly take a step back to think about their strategies and make adjustments if necessary. The importance of reflection is supported by Wade and Yarbrough (1996:64) as follows:

As we reflect, we discover the links between different aspects of our life experience. Past experiences are reconsidered in light of new information. Reflection allows us to draw conclusions about our past experience and develop new insights that we can apply to our future activities.

In this research, pre-service teachers were expected to reflect on their aesthetic understanding and incorporate these aesthetic techniques pertaining to a strategy that they experienced as captivating in their coursework to their practice, thereby infusing classroom learning with the real life experiences. Konklin (1970) noted that the intention between the aesthetic processes is to link the subject matter and to help in the understanding and appreciation of this subject matter.

The majority of South African teachers lack the knowledge and skills to teach in a 21st century global and technologically demanding environment (Department of Education; 2007:4). 
In a statement by Ron Swartz (the Head of Education in Western Cape) he alluded to the Department of Education's focus on skills. He added that in the ten years after democracy the primary objective of education was to "provide quality education for all' (Attwell, 2006). However, with large class sizes, increased teaching workloads and administrative tasks (Hall, Altman, Nkomo, Peltzer and Zuma, 2005), teachers are left with little time to think about crafting their lessons to engage students aesthetically.

There is a lack of current research promoting teachers' understanding on the concept of aesthetics and the use of aesthetics as an agent of change to alter pre-service teachers' early preconceptions of teaching. The research reported in this article therefore sought to explore how pre-service teachers interpret, apply and create different ways of teaching through aesthetics.

\section{RESEARCH METHODOLOGY}

Where human experience is central to a study and particularly where both experience and perception are 'under the microscope' and inductive, aninterpretiveapproachiswarranted through qualitative methods. The research design type is a case study as it constitutes a 'bounded' study of students' written responses in a specific discipline over a specific period of time (Cohen et al. 2007). In this research, the phenomenon of interest was students' written feedback pertaining to their experiences and perceptions when engaged in work-integrated activities during school experience. Students spend an extended period of time at schools where they are involved with both teaching and reflection under the supervision of a mentor teacher. In the research analysis students' responses about their experiences were analysed through a critical lens in an attempt to address social issues that may have arisen (Henning et al., 2004:23).

Thirty per cent of students' writings were selected randomly from a total of 300 students ensuring that an unbiased sample was selected (Cohen et al., Manion and Morrison, 2007:110). Institutional ethics clearance was obtained for the study. This included all participants' right to privacy and confidentiality. Qualitative data was analysed by means of thematic content analysis in order to explain the experiences of pre-service teachers when implementing teaching strategies that they had found to be captivating in lectures. Data was coded, resulting in the grouping of evidence and labelling of ideas so that they reflected increasingly broader perspectives (Clark and Cresswell, 2008:132).

\section{FINDINGS AND DISCUSSION}

Students were asked to reflect on the following with regard to their teaching during practice sessions: First, they were asked to refer to a teaching strategy used in any of their lectures at the university that had captivated them and to provide a brief outline of this strategy and its effectiveness in enhancing their understanding of the content that was taught. Next they were asked to apply this same teaching strategy in a lesson that they taught during their school visit, followed by a critical reflection of its success in the classroom.
The following themes that emerged in our findings are discussed below: aesthetic teaching strategies; constructing knowledge; nurturing social competences and encouraging innovative talents

From our analysis, we noted that the teaching strategies that students had referred to as captivating in their lectures were all learner-centred. From our sample, $45 \%$ of students found group work to be the most captivating of teaching strategies followed by $35 \%$ of students who preferred the whole class discussion method at lectures. Acting, demonstrations, experiments and games captivated $13 \%$ of the students while $7 \%$ of students preferred questioning as a teaching strategy.

One of the reasons that the students provided in support of the selected teaching strategies being captivating was knowledge construction. Students' justification for describing their learning experiences in the lecture as captivating was that these experiences contributed to their having a deeper understanding of the content knowledge that was taught at lectures. Such justification permeated through all of the above teaching strategies. Students were constructing knowledge about the content by exchanging ideas amongst fellow students within the group. Pre-service teachers' perceptions seem to be in agreement with the views of Konklin (1970) who argued that the intention between the aesthetic processes is to link the subject matter and to help in the understanding and appreciation of subject matter.

The students indicated that they learnt better from other students as it was sometimes difficult to understand certain difficult concepts when taught by the lecturer. Concepts which are sometimes taught by lecturers in abstract language are explained by students in everyday language. This view echoes those of scholars such as Muller (2001:13) who indicated that the codified language used to present academic knowledge in lectures is different from the language of everyday discourse used by students. As such, student teachers find it difficult to understand academic knowledge presented by teacher educators.

Students who found class discussions enjoyable commented positively about the use of videos, slides, pictures, movie clips or case studies using real life scenarios as a valuable tool to start the discussion. This approach provided the base upon which new knowledge could be built, it captivated the students' attention and set the scene for a productive class discussion. The students also commented that the content knowledge displayed by the lecturers was very deep which enabled the lecturers to steer the discussion in a direction that allowed for students to think very critically about issues relevant to the lecture.

The positives of applying these methods in the classroom were that they also encouraged student teachers to think more critically about issues that were being taught and to evaluate their own ideas against insights provided by students. The students found that the learners in their class were very interested in the lesson especially when it was relevant to their own lives and particular circumstances. It encouraged both the 
student teacher and the learners in the classroom to reflect. Using media as an aid in the selected strategy helped students to remain focused on the outcomes of the lesson and generated greater discussion and questioning. Content knowledge was also enhanced as they observed learners explaining to each other in their mother tongue. It also enhanced teaching and learning as this teaching strategy enabled the student teacher to identify students within groups who were struggling with concepts.

The pre-service teachers reflected that they needed to be very familiar with the content taught in order for them to be able to facilitate each of these strategies successfully. They had to have a strong grounding in the content knowledge being taught as it requires constant effort to ensure that students remain focused and to clarify any misconceptions about the topic. Listening to learners in the classroom was also identified as an important strategy by which to lead learners through questioning to think more deeply about issues.

However, some pre-service teachers experienced difficulties in applying aesthetic strategies such as group work in large classes, and they acknowledged that they still needed to improve their content knowledge when managing class discussions. Students' reflections on the use of this method were that it generated much excitement in the class. They indicated that maintaining discipline could become very problematic for a pre-service teacher in such a situation, as suggested by the following response from one of the participants: 'Getting excited; made it difficult for me to think straight; did not know what to do when the class got too noisy.' Upon reflecting, the pre-service teachers realised that it was important to keep calm when things appeared to be going wrong. They focused on the learning that was taking place and realised that the 'noise' was actually a positive indication that knowledge was being constructed through the different exchange of voices in the classroom.

The next theme was building social skills, which included listening skills, freedom to express oneself, and the ability to debate. These skills contributed towards developing feelings of appreciation and the personal satisfaction of being heard. The pre-service students also indicated that it improved their confidence as it was not so intimidating to contribute towards discussions in small groups as in the presence of the entire class. Developing these social competences not only encouraged a deeper level of understanding of the content but also an understanding of others. It promoted an understanding of students from different backgrounds as it fostered closer interaction among students within the group.

Pre-service teachers observed that constructivist approaches to learning contributed towards building social skills amongst learners as they found that it encouraged co-operation and participation among group members. Pre-service teachers observed that quiet learners became more involved in the discussion. They also got to know the learners in the classroom better. When both pre-service teachers and learners used enjoyable strategies in the classroom, a better understanding and greater appreciation were fostered among the learners.
At the same time, it provided an opportunity for the teacher to gain an understanding of the learners through a different lens, the lens of aesthetic engagement.

The pre-service students experienced some frustrations in using these methods. In some cases problems arose making it difficult to implement the teaching strategy. Some of the problems were ill-discipline and poor time management. However, the students displayed innovativeness in attempting to address these issues. For example, they adapted the approach to suit the age group of the learners in the class by using visual aids such as pictures and models to enhance the group discussion. To prevent a few learners from dominating the group discussion, one student rolled up a sheet of paper to represent a microphone and moved this around the group with the instruction that learners in the group were only allowed to speak if they were in possession of the 'mike'. Another student adapted the group discussion to minimize discipline problems and got students to write their views on paper, similar to the quiet round robin method according to which one student starts the discussion, passes the paper to the next to add their comments, thus ensuring that they do not repeat views. All students' voices are heard, but silently.

\section{DISCUSSION}

The students who participated in this research had to reflect by putting on two different thinking caps. The first was reflecting as a student on a lecture that they perceived as captivating; the second was reflecting as a student teacher on their own classroom practices when applying the same teaching strategy that they found captivating in their lectures. In analysing the above responses holistically, we discovered that the pre-service teachers' responses regarding enjoyment of the aesthetic teaching methods in lectures seemed to correlate with what they believed their learners experienced in the class. Pre-service teachers had first-hand experiences with the very strategies that they then applied in the classrooms during their school visits. Therefore, they were aware of the possible outcomes in their own classroom practices and were able to compare the successes of their classroom teaching strategies to their own learning experiences. Drawing on such positive prior experiences can provide opportunities for pre-service teachers to expand on or explore other creative avenues for teaching and learning as they are already familiar with how the strategy is used and the values it brings to learning.

While they recognised the value of using such a strategy in teaching and learning, they also acknowledged the importance of content knowledge, planning and management that is involved to ensure that both teaching and learning are experienced aesthetically. The pre-service teachers were able to see the link between all the elements that need to be considered for a lesson to be successful. Success in this study was measured by both the teachers' and the learners' enjoyment of the lesson. The fact that the pre-service students could reach this level of critical reflection signalled that using aesthetics as a tool enabled students to experiment with teaching strategies so as to extend the boundaries of learning for themselves and the learners in the class. 


\section{CONCLUSION AND RECOMMENDATIONS}

We aimed to use aesthetics as a lens that our pre-service students could use to experiment with a teaching strategy that they had identified. The findings indicated the positive influence of aesthetically enjoyable and engaging teaching strategies on pre-service students' understanding of content knowledge taught in lectures. Reports by pre-service students regarding their application of these strategies at schools during their school experience were equally positive. It was evident that their personal, first-hand experiences with the selected strategy had made it possible for them to reflect critically before, during and after the lesson. It is recommended that for effective teaching to take place, pre-service teachers need to take 'full account of the multi-dimensional cultural world of the learner' and therefore adopt a multi-dimensional approach that includes aesthetics in their practice. We believe that using the lens of aesthetic engagement to judge the success of teaching and learning can be the answer to teaching for lifelong skills and not just for examinations and tests.

\section{REFERENCES}

Attwell, P. 2006. Western Cape Ready for FET curriculum in schools. Accessed from http://wced.wcape.gov.za.\%target

Burbules, N. \& Bruce, B. 2001. Theory and research on teaching as dialogue. In Handbook on research on teaching (4th ed., pp. 1102-1121). Edited by Richardson, V. Washington, DC: America Educational Research Association.

Clark, V.L.P. \& Cresswell, J.W. 2008. The Mixed Methods Reader. Sage Publications, Thousand Oaks, California.

Cohen, L., Manion, L., \& Morrison, K. 2007. Research Methods in Education. Routledge, Abingdon, Oxon.

Crawford, D. W. 1987. 'Aesthetics in Discipline-Based Art Education', Journal of Aesthetic Education, 21(2): Special Issue: Discipline-Based Art.

Darling-Hammond, L. 2008. Teacher learning that supports student learning. In Presseisen, B.Z. (Ed). Teaching for Intelligence. Corwin Press, Thousand Oaks, California.

Department of Basic Education and Higher Education and Training. 2011. Integrated Strategic Planning Framework for Teacher Education and Development in South Africa. Pretoria. South Africa.

Department of Education. 2007. National Education Policy Framework for Teacher Education and Development in South Africa. Government Gazette No. 29832. Vol. 502. Pretoria. DoE.

Dewey, J. 1904. THE RELATION OF THEORY TO PRACTICE IN EDUCATION - publication details needed.

Drake, S.M. 1998. Creating Integrated Curriculum. Proven ways to increase student learning. Corwin Press, Thousand Oaks, California, USA.

Frederick, R, Cave, A. \& Perencevich, K. C. 2010. 'Teacher candidates' transformative thinking on issues of social justice', Teaching and Teacher Education, 26:315-322.

Ganger, D. A. 2006. 'Teaching aesthetics and aesthetic teaching: Toward a Deweyan perspective', Journal of Aesthetic Education, 40 (2):45-66.

Gaudelli, W. \& Hewitt, R., 2010. 'The aesthetic potential of global issues curriculum', The Journal of Aesthetics Education, 44(2), 83-99.

Goldman, K. L. 2010. Maxine Greene: Influence on the life and work of a dynamic Educator. Journal of Educational Controversy. Available from http://www. wce.wwu.edu/resources/CEP/eJournal/v005n001/a019.shtml. (Accessed 25 February 2011).

Gordon, M. 2007. 'How do I apply this to my classroom?' Relating theory to Practice. In M. Gordon \& Brien, T.O (Eds), Bridging Theory and Practice in Teacher Education, 119-131. Sense Publishers, Netherlands.

Hall. E., Altman, M., Nkomo, N., Peltzer, K. \& Zuma, K. 2005. Potential Attrition in Education. The impact of job satisfaction, morale, workload and HIV/AIDS. Report presented to the ELRC. Independent Publishers Group. South Africa.

Henning, E, Van Rensburg, WA \& Smit, B. 2004. Finding your way in qualitative research. Pretoria: Van Schaik.

Heron, J., \& Reason, P. 1997. 'A Participatory Inquiry Paradigm', Qualitative Inquiry, 3(3), 274-294.

Hook, B.1994. Teaching to transgress: Education as the practice of freedom. New York: Routledge.

Hofer, B. 2010. 'Personal epistemology in Asia: Burgeoning research and future directions', The Asia-Pacific Education Researcher, 19(1), 179-184.

Lam, A. 2000. 'Tacit Knowledge, Organizational Learning and Societal Institutions: 
An Integrated Framework', Organization Studies, 21(3), 487-513.

Macann, E. 2010. Stille: The Art of being Silent. Available from http://researcharchive.vuw.ac.nz/handle/10063/1659. Accessed: 29 August 2013.

Muis, K. 2004. 'Personal epistemology and mathematics: A critical review and synthesis of research', Review of Educational Research, 74(3), 317-377.

Muller, J. 2000. Reclaiming Knowledge. Social theory, curriculum and education policy. Routledge Falmer, London.

Palmer, J., \& Neal, P. 1994. The handbook of environmental education. Routledge, London.

Pretorius, S.G. 2004. Issues and trends in teacher education in international perspective. Africa Education Review, 1(1):46-64. Accessed from http://dx.doi. org/10.1080/18146620408566269.

Rhodes, L.K. \& Bellamy, G.T.1999. 'Choices and consequences in the renewal of teacher education', Journal of Education for Teaching, 25 (3): 233-245.

Sparshott, F. 1982. The theory of arts. Princeton., NJ: Princeton University Press.

Shulman, L.S. 1998. 'Theory, Practice, and the Education of Professionals', The Elementary School Journal (Special Issue: John Dewey: The Chicago Years), 98(5): 511-526.

Stofflett, R., \& Stoddart, T. 1994. 'The ability to understand and use conceptual change pedagogy as a function of prior content learning experience', Journal of Research in Science Teaching, 31(1): 31-51.

Sundin, B. 2000. 'Aesthetics and Education: An ill-matched couple?' International Journal of Music Education,36: 4-13.

Wade, R.C., \& Yarbrough, D.B. 1996. 'Portfolios: A tool for reflective thinking in Teacher Education?’ Teaching and Teacher Education, 12 (1): 63-79.

Watts, M. 1998. 'Towards Critical constructivist teaching', International Journal of Science Education,10 (2): 173-185.

Wubbels, T. 1992. 'Taking account of student teachers' preconceptions' Teaching and Teacher Education, 8(2): 137-149.

Zangwill, N. 2014. 'Aesthetic Judgment', The Stanford Encyclopedia of Philosophy (Fall 2014 Edition), Edward N. Zalta (ed.). 